\title{
Interleukin $1 \beta$ induces gastric epithelial cell matrix metalloproteinase secretion and activation during Helicobacter pylori infection
}

\author{
M Gööz , M Shaker, P Gööz, A J Smolka
}

See end of article for authors' affiliations

Correspondence to: Dr A J Smolka, Department of Medicine CSB $921 \mathrm{E}$, Medical University of South Carolina, 96 Jonathan Lucas St, Charleston, SC 29425, USA;

smolkajן@musc.edu

Accepted for publication 30 April 2003

\begin{abstract}
Background and aims: Matrix metalloproteinases (MMPs) are endopeptidases with roles in extracellular matrix remodelling, cell proliferation, and inflammatory processes. We showed previously that Helicobacter pylori infection of human gastric adenocarcinoma (AGS) cells increased epithelial secretion of epithelial MMP- 1 and MMP-3 and bacterial secretion of MMP-3- like activity. In the present study, we sought to characterise the role of interleukin (IL)-1 $\beta$ in $H$ pylori induced secretion of epithelial MMPs.

Methods and results: AGS cells were treated with $\mathrm{H}$ pylori and/or IL-1 $\beta$. Comparable IL-8 secretory responses $(-1700 \mathrm{ng} / \mathrm{ml})$ measured by ELISA were induced by $2.0 \mathrm{ng} / \mathrm{ml} \mathrm{IL-1 \beta}$ and by $H$ pylori at a multiplicity of infection (MOI) of 50 . The same IL- $1 \beta$ and $H$ pylori concentrations induced comparable increases in AGS cell caseinolytic activity at $60 \mathrm{kDa}$. MMP-3 monoclonal antibody immunoblots of AGS cell conditioned media detected immunoreactive bands at $71 \mathrm{kDa}$ and $56 \mathrm{kDa}$. $\mathrm{H}$ pylori $(\mathrm{MOl}=50-100)$ induced dose dependent increases in both bands whereas IL-1 $\beta(0.2-2 \mathrm{ng} / \mathrm{ml})$ induced dose dependent increases only in the $71 \mathrm{kDa}$ band, which was identified as a MMP-3/TIMP-3 (tissue inhibitor of metalloproteinases 3) heterodimer. AGS/H pylori conditioned media expressed 24 times more MMP-3 activity than AGS/IL-1 $\beta$ conditioned media. There was a strong interaction between IL- $1 \beta$ and $H$ pylori on MMP-3 secretion.

Conclusions: We conclude that IL- $1 \beta$ induces gastric epithelial cell MMP-3 secretion, contributing to epithelial tissue destruction during $H$ pylori infection. However, other bacterial/host factors are needed to mediate the full gastric epithelial cell MMP-3 secretory response induced by $\mathrm{H}$ pylori infection.
\end{abstract}

$\mathrm{H}$ elicobacter pylori is a causative agent of superficial gastritis, gastric and duodenal ulcers, atrophic gastritis, and gastric cancer. ${ }^{1}$ Gastric colonisation by $H$ pylori provokes host inflammatory responses associated with elevated levels of mucosal cytokines (for review see Crabtree $^{2}$ ). The inflammatory interleukins IL- $1 \beta$, IL-6, and IL-8, and tumour necrosis factor $\alpha$ (TNF- $\alpha)$, have been detected in patients infected by cytotoxin associated protein $\left(\mathrm{cagA}^{+}\right)$strains of $\mathrm{H} \mathrm{pylori}^{3}$ and in in vitro cultures of antral gastric biopsies from $H$ pylori infected patients. ${ }^{4}$ In vitro studies with human gastric cell lines have confirmed in vivo observations that $H$ pylori stimulates IL-8 secretion by gastric epithelial cells. ${ }^{5}$

Gastric colonisation by $H$ pylori also induces a transient period of achlorhydria. ${ }^{2}$ Factors contributing to altered gastric acid secretion during $H$ pylori infection include urease activity, ${ }^{6}$ a soluble protein of $46 \mathrm{kDa}^{7}$ and certain fatty acid components of $H$ pylori lipopolysaccharide. ${ }^{8}$ In addition, $H$ pylori induced achlorhydria may also be mediated by IL-1 $\beta$ which has been shown to inhibit gastric acid secretion in rats. ${ }^{9}$ We have shown that acute $H$ pylori infection of gastric epithelial cells transiently transfected with human $\mathrm{H}, \mathrm{K}$ ATPase $\alpha$ subunit promoter downregulates promoter activity, ${ }^{10}$ a finding which may correlate mechanistically with decreased acid output in acute $H$ pylori infection in vivo.

Bacterial factors also mediate gastric epithelial damage induced by $H$ pylori infection. ${ }^{11}$ Strain specific bacterial factors include cagA, the protein product of the cagA gene, which is injected into host cells during $H$ pylori infection and stimulates dephosphorylation of host- cell proteins. ${ }^{12}$ Other bacterial factors are the vacuolating toxin (VacA) ${ }^{13}$ and the protein product of the $i c e A$ gene $^{14}$ which are associated with more severe clinical outcome.
As $H$ pylori strains with similar known virulence markers can induce several distinct patterns of inflammation, ${ }^{15}$ the roles of other bacterial and host factors in mediating $H$ pylori induced gastroduodenal epithelial damage are of considerable interest. Matrix metalloproteinases (MMPs) are extracellular matrix degrading endopeptidases with roles in inflammatory processes, cell migration, and tumour growth and metastasis. ${ }^{16}$ In normal human and rabbit gastric mucosa, MMP-1, MMP-2, MMP-9, and tissue inhibitor of metalloproteinases 2 (TIMP-2) have been detected using immunocytochemistry. ${ }^{17}$ Enhanced expression of matrilysin, collagenase, and stromelysin-1 (MMP-3) in gastrointestinal ulcers has been reported. ${ }^{18}$ We have shown that $H$ pylori infection of AGS cells increases secretion of epithelial cell MMP-1 and MMP-3 and enhances secretion of TIMP- $3 .{ }^{19}$ Furthermore, our data indicated that bacterial MMP3-like activity and TIMP-3-like immunoreactivity contribute to the host-cell response. ${ }^{19}$

As noted above, IL-1 $\beta$ has been implicated in the development of a gastric inflammatory response and transient achlorhydria, ${ }^{2}$ and plays roles in several pathways leading to gastric injury and tissue destruction. Secreted MMP-1 and MMP-3 levels are upregulated by IL-1 $\beta$ in human intestinal mucosa ${ }^{20}$ and in fibroblasts. ${ }^{21}$ Furthermore, polymorphisms of the human IL-1 $\beta$ gene promoter are associated with an

Abbreviations: IL, interleukin; TNF- $\alpha$, tumour necrosis factor $\alpha$; MOI, multiplicity of infection; MMPs, matrix metalloproteinases; TIMP, tissue inhibitor of metalloproteinases; vacA, vacuolating cytotoxin; $\operatorname{cagA}$, cytotoxin associated protein; PBS, phosphate buffered saline; ELISA, enzyme linked immunosorbent assay; SDS-PAGE, sodium dodecyl sulphate-polyacrylamide gel electrophoresis. 
increased risk of gastric cancer, ${ }^{22}$ and involvement of IL- $1 \beta$ in mucosal apoptosis induced by $H$ pylori has also been proposed..$^{15}$ As both MMPs and the cytokine cascade are implicated in tissue destruction and are activated during $H$ pylori infection, in the present study we tested the hypothesis that activation of gastric epithelial MMPs by $H$ pylori is mediated by the proinflammatory cytokine IL-1 $\beta$.

\section{MATERIALS AND METHODS}

Cell culture media and additives were acquired from Cellgro Mediatech (Herndon, Virginia, USA), and fetal bovine serum was obtained from Atlanta Biologicals (Norcross, Georgia, USA). TIMP-3 (AB802) polyclonal antibody and MMP-3 (MAB 1339) monoclonal antibody were purchased from Chemicon Inc. (Temecula, California, USA). Secondary antibodies were obtained from Rockland Immunochemicals Inc. (Gilbertsville, Pennsylvania, USA) and Jackson Immunoresearch Laboratories Inc. (West Grove, Pennsylvania, USA). Control MMPs and TIMPs prepared from human skin fibroblast conditioned media were obtained from Sigma (St Louis, Missouri, USA). Fluorogenic substrates for measurement of MMP enzyme activity were purchased from Bachem Inc. (Torrance, California, USA). All other reagents were of molecular biology grade or the highest grade of purity available.

\section{Cells and bacteria}

Human gastric adenocarcinoma cells (AGS cells, ATCC CRL 1739) were maintained in AGS medium (Ham's F-12, 10\% fetal bovine serum, 100 units $/ \mathrm{ml}$ penicillin $\mathrm{G}, 0.25 \mu \mathrm{g} / \mathrm{ml}$ amphotericin $\mathrm{B}, 100 \mu \mathrm{g} / \mathrm{ml}$ streptomycin) at $37^{\circ} \mathrm{C}$ in a $5 \% \mathrm{CO}_{2} /$ $95 \%$ air incubator and used between passages 42 and 56 . A strain of $H$ pylori positive for vacuolating cytotoxin $(v a c A+)$, cytotoxin associated protein $\left(\mathrm{cagA}^{+}\right)$, and urease (ATCC number 49603) was cultured on 5\% horse blood agar plates (Remel; Lenexa, Kansas, USA) incubated at $37^{\circ} \mathrm{C}$ in sealed microaerophilic pouches (BBL Campy Pouch; Becton Dickinson, Cockeysville, Maryland, USA). Cultures were routinely screened for urease activity.

\section{Cell treatments}

For $H$ pylori infection of AGS cells, $H$ pylori were harvested between 48 and 72 hours after inoculation of agar plates, resuspended in sterile phosphate buffered saline (PBS), and counted by absorbance at $600 \mathrm{~nm}\left(\mathrm{l} \mathrm{OD}_{600 \mathrm{~mm}}=2.4 \times 10^{8}\right.$ colony forming units $/ \mathrm{ml})$. AGS cells $\left(2.5 \times 10^{6}\right)$ were seeded into T-75 flasks and infected at $90 \%$ confluence with $H$ pylori at multiplicities of infection (MOI) of 50-100 or incubated with IL- $1 \beta(0.2-20 \mathrm{ng} / \mathrm{ml})$ in serum free Ham's F12 culture medium for 24 hours. Controls included uninfected/untreated AGS cells and $H$ pylori alone (in the same amounts as used for infection) which were cultured in serum free medium for the same length of time. Conditioned media were centrifuged for 10 minutes at $4000 \mathrm{~g}$ to remove cells and bacteria, and serum free media were concentrated $100-130 \times$ by ammonium sulphate precipitation. Unconditioned serum free medium was concentrated and used as a negative control. Media aliquots were stored at $-70^{\circ} \mathrm{C}$ until used.

\section{Measurement of IL-8 secretion}

IL-8 content of culture media conditioned by untreated, IL-1 $\beta$ treated, or $H$ pylori infected AGS cells was measured using an IL-8 enzyme linked immunosorbent assay (ELISA) kit according to the manufacturer's instructions (R\&D Systems Minneapolis, Minnesota, USA).

\section{Zymography}

Concentrated AGS cell culture media were mixed with sodium dodecyl sulphate- polyacrylamide gel electrophoresis (SDSPAGE) sample buffer ( $10 \%$ glycerol, $2 \%$ SDS, $63 \mathrm{mM}$ Tris, $\mathrm{pH}$ 7.0) without reducing agent and applied to non-reducing $10 \%$ acrylamide gels containing $0.1 \%$ gelatin, or to non-reducing $4-16 \%$ acrylamide gels containing $0.1 \%$ casein (NuPAGE; Novex, Encinitas, California, USA). Electrophoresis was carried out for 90 minutes at $125 \mathrm{~V}$ at room temperature, and resolved proteins were renatured in situ by immersing the gels in $2.7 \%(\mathrm{w} / \mathrm{v})$ Triton-X 100 for 30 minutes at room temperature. The gels were then rinsed in zymogram developing buffer (Novex) for 30 minutes and incubated overnight at $37^{\circ} \mathrm{C}$ in the same buffer. Gelatinolytic or caseinolytic activity in the gels was visualised as negative staining with Coomassie Brilliant Blue.

\section{Enzyme activity assay}

MMP activity of unconcentrated and 100-130× concentrated serum free media conditioned by untreated, IL- $1 \beta$ treated, and/or $H$ pylori infected AGS cells, or by $H$ pylori culture, was measured using the fluorogenic MMP-3 specific synthetic peptide substrate Mca- Arg-Pro-Lys-Pro-Val-Glu-Nva-TrpArg-Lys(Dnp)-NH $\mathrm{NH}_{2}$ Substrate fluorescence evoked by metalloproteinase activity was measured for 200 seconds in an Aminco-SLM DW2 spectrofluorimeter (excitation $328 \mathrm{~nm}$, emission $399 \mathrm{~nm}$ ) with a slit width of $1 \mathrm{~nm}$ and sensitivity of $800 \mathrm{~V}$.

\section{Immunoprecipitation}

MMP-3 antibody was covalently coupled to cyanogen bromide activated agarose beads (Sigma, St Louis, Missouri, USA) in binding buffer $\left(0.1 \mathrm{M} \mathrm{NaHCO}_{3} / 0.5 \mathrm{M} \mathrm{NaCl}, \mathrm{pH}\right.$ 7.6) for two hours at room temperature. Reactive sites were blocked with 0.1 M Tris buffer ( $\mathrm{pH} \mathrm{8.0)} \mathrm{for} \mathrm{one} \mathrm{hour} \mathrm{at} \mathrm{room} \mathrm{temperature,}$ and the beads were washed with $50 \mathrm{mM}$ diethylamine and then with PBS ( $\mathrm{pH}$ 7.4). Coupling efficiency was assessed by comparison of antibody banding densities on SDS-PAGE gel before and after the coupling reaction. Concentrated conditioned media from IL- $1 \beta$ treated and $H$ pylori infected AGS cell cultures were desalted by dialysis against non-denaturing buffer $(50 \mathrm{~mm}$ Tris $\mathrm{HCl}$, pH 7.4, $150 \mathrm{mM} \mathrm{NaCl}, 1 \%$ Triton $\mathrm{X}-100,0.5 \%$ Na-deoxycholate, 1 mM EDTA, $0.1 \%$ SDS, $10 \mu \mathrm{l} / \mathrm{ml}$ protease inhibitor cocktail III (Calbiochem, San Diego, California, USA), and $1 \mathrm{mM}$ PMSF). Samples were incubated with the antibody coupled beads in non-denaturing buffer at $4^{\circ} \mathrm{C}$ overnight with constant rotation. After removal of supernatants, the beads were washed with binding buffer, eluted with $50 \mathrm{mM}$ diethylamine, and the eluents analysed by TIMP-3 immunoblotting.

\section{Immunoblotting}

Aliquots of concentrated media conditioned by untreated, IL- $1 \beta$ treated, or $H$ pylori infected AGS cells, or by $H$ pylori culture, and material eluted from MMP-3 antibody coupled beads were mixed with SDS-PAGE sample buffer without reducing agent and heated at $95^{\circ} \mathrm{C}$ for five minutes. Electrophoresis was carried out on $4-12 \%$ or on $10 \%$ acrylamide Bis-Tris gels (NuPAGE; Novex) for 35 minutes at $200 \mathrm{~V}$. Resolved proteins were transferred to $0.2 \mu \mathrm{m}$ nitrocellulose membranes (Osmonics, Westborough, Massachusetts, USA) and blocked with $5 \%$ non-fat dry milk for two hours. Protein replicas were washed $3 \times$ in TTBS $(20 \mathrm{mM}$ Tris, $0.5 \mathrm{M} \mathrm{NaCl}, \mathrm{pH} 7.5,0.05 \%$ Tween-20), and incubated overnight at room temperature in the appropriate dilutions of MMP or TIMP antibodies. The replicas were then washed $3 \times$ in TTBS and incubated for one hour at room temperature in appropriate dilutions of secondary antibodies. Immunoreactive protein bands were visualised using enhanced chemiluminescence and recorded on ECL Hyperfilm (ECL kit, Amersham Pharmacia, Piscataway, New Jersey, USA). Immunoblots shown in this study are representative replicates selected from at least three experiments.

\section{Protein measurement}

Culture medium protein concentrations were measured using Bio-Rad protein assay reagent (Bio-Rad, Hercules, California, 


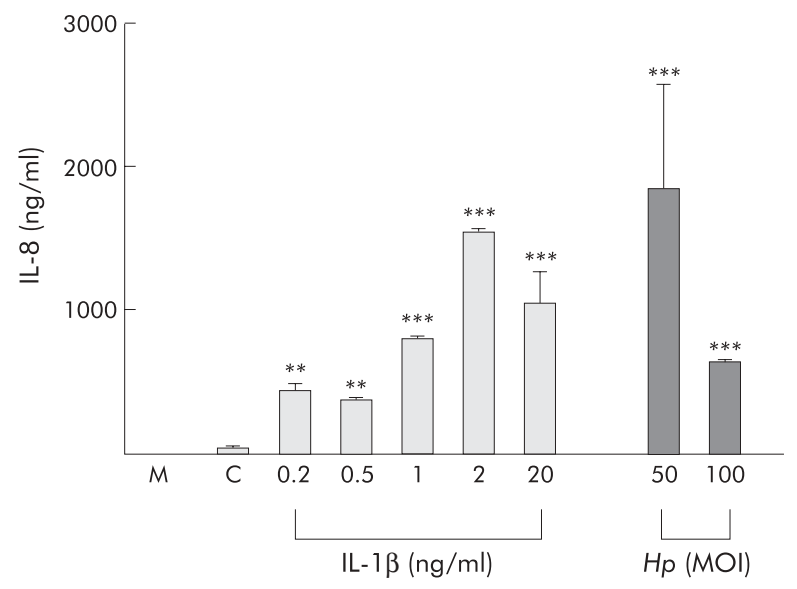

Figure 1 Interleukin (IL)-8 secretory response in AGS cells induced by IL-1 $\beta(0.2-20 \mathrm{ng} / \mathrm{ml}$ ) and Helicobacter pylori (Hp) (multiplicity of infection (MOI) $=50$ and 100 ), as measured by enzyme linked immunosorbent assay. $M$, cell culture medium alone; $C$, cell culture medium from untreated AGS cells. $n=3,{ }^{* *} p<0.01,{ }^{* *} p<0.001$ versus untreated cells.

USA). The protein concentration of serum free unconditioned medium was $0.38(0.08) \mathrm{mg} / \mathrm{ml}$, that of AGS conditioned medium was $0.75(0.17) \mathrm{mg} / \mathrm{ml}$, that of infected AGS conditioned medium was $1.96(0.29) \mathrm{mg} / \mathrm{ml}$, and that of $H$ pylori conditioned medium was $0.82(0.21) \mathrm{mg} / \mathrm{ml}$. Data are expressed as mean (SEM), $\mathrm{n}=6$. Culture medium aliquots ( 5 $\mu \mathrm{l}$ ) were used for enzyme activity assays. For zymographic and immunoblot assays, $18 \mu \mathrm{l}$ of culture medium aliquots were applied to each lane.

\section{Data analysis}

Densitometric analysis of zymograms and immunoblots was carried out using image analysis software (Scion Corporation). Data are expressed as per cent of control activity (the densitometric intensity of uninfected AGS cell conditioned medium was set to $100 \%$ ) and are shown below the gels. Enzyme activity data were analysed by linear regression and were expressed as initial reaction velocity (fluorescence unit/s). Data comparisons were made using the Student's $t$ test and ANOVA, with $\mathrm{p}<0.05$ regarded as significant. All experiments were carried out at least three times.

\section{RESULTS}

\section{IL-8 secretory response induced by IL- $1 \beta$ and $H$ pylori}

$\mathrm{H}$ pylori and IL-1 $\beta$ have previously been shown to induce gastric epithelial cell IL-8 secretion. ${ }^{5}$ As a first step in clarifying the role of IL-1 $\beta$ in MMP mobilisation by AGS cells, we determined the concentrations of IL-1 $\beta$ and $H$ pylori that would induce comparable levels of AGS cell IL-8 secretion. AGS cells were treated with either IL-1 $\beta(0.2-20 \mathrm{ng} / \mathrm{ml})$ or infected with $H$ pylori (MOIs of 50 and 100) in serum free Ham's F-12 medium. IL-8 contents of unconcentrated conditioned supernatants were measured by ELISA. As shown in fig l, IL-1 $\beta$ dose dependently increased the IL-8 secretory response of AGS cells. The IL-8 content of medium conditioned by untreated AGS cells was 39.2 (2.1) ng/ml (fig lC). Comparable IL-8 secretory responses (154l (26) ng/ml and 1840 (729) $\mathrm{ng} / \mathrm{ml}$ ) were induced by $2.0 \mathrm{ng} / \mathrm{ml} \mathrm{IL-1} \beta$ and by $H$ pylori at $\mathrm{MOI}=50$, respectively. In all subsequent experiments, AGS cells were treated with these IL- $1 \beta$ and $H$ pylori concentrations.

\section{Casein zymography of AGS cell conditioned media}

MMP activity secreted by AGS cells during IL-1 $\beta$ treatment or $H$ pylori infection was assessed by electrophoresis of $130 \times$ concentrated serum free cell culture media through casein containing zymogram gels. To study the possible interaction
A
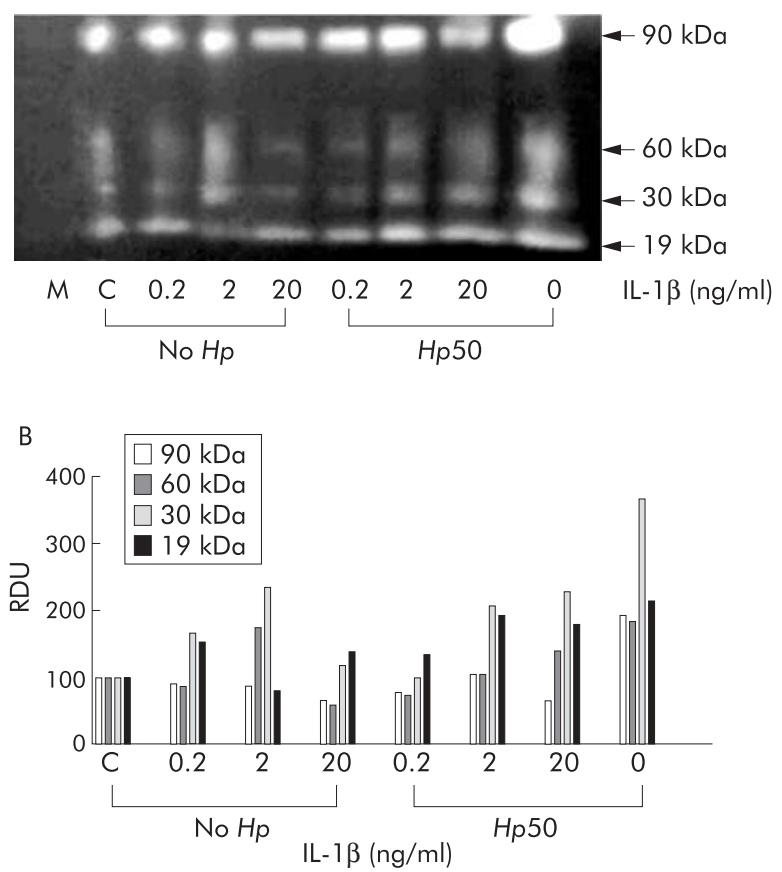

Figure 2 (A) Caseinolytic activity of interleukin (IL)- $1 \beta$ treated $(0.2-20 \mathrm{ng} / \mathrm{ml}$, No Hp) and/or Helicobacter pylori (multiplicity of infection (MOI) $=50, H p 50$ ) infected AGS cell conditioned media, as measured by casein zymography. Lane $M$, cell culture medium alone; lane $\mathrm{C}$, supernatant of untreated AGS cells. Calculated molecular masses of caseinolytic bands are shown on the right. (B) Densitometric analysis of $90 \mathrm{kDa}, 60 \mathrm{kDa}, 30 \mathrm{kDa}$, and $19 \mathrm{kDa}$ caseinolytic bands. The zymogram is a representative replicate selected from three experiments. RDU, relative densitometric units.

between IL-1 $\beta$ and $H$ pylori, we included cell supernatants from IL-1 $\beta$ treated $(0.2-20 \mathrm{ng} / \mathrm{ml})$ and $H$ pylori infected $(\mathrm{MOI}=50)$ cells. Figure 2 shows a typical caseinolytic zymogram together with densitometric analysis of caseinolytic gel bands. Caseinolytic activities in unconditioned medium and in medium conditioned by untreated AGS cells are shown in lanes $M$ and $C$, respectively. No caseinolytic activity was detected in unconditioned medium. Culture medium from untreated AGS cells showed bands of caseinolytic activity at $\sim 90 \mathrm{kDa}$ and $19 \mathrm{kDa}$ and traces of activity at $\sim 60 \mathrm{kDa}$ and $30 \mathrm{kDa}$. These data are consistent with our previous findings. ${ }^{3} \mathrm{IL}-1 \beta(0.2-2 \mathrm{ng} / \mathrm{ml})$ treatment dose dependently increased caseinolytic activity at $60 \mathrm{kDa}$ and $30 \mathrm{kDa}$ and decreased activity at $19 \mathrm{kDa}$. However, cell treatment with $20 \mathrm{ng} / \mathrm{ml} \mathrm{IL-1 \beta}$ decreased caseinolytic activity at $90 \mathrm{kDa}, 60$ $\mathrm{kDa}$, and $30 \mathrm{kDa}$. Densitometric analysis of caseinolytic bands in fig 2 indicated that IL- $1 \beta$ and $H$ pylori concentrations inducing comparable IL- 8 secretory responses $(2 \mathrm{ng} / \mathrm{ml}$ and $\mathrm{MOI}=50$, respectively) induced comparable increases in AGS cell MMP activity at $60 \mathrm{kDa}(175 v 183$ relative densitometric units). Comparable caseinolytic activities were induced by $H$ pylori at MOI of 100 and at MOI of 50 (data not shown). Medium conditioned by $H$ pylori alone showed weak caseinolytic activity at $60 \mathrm{kDa}^{3}$ (data not shown).

\section{MMP-3 secretion by IL- $1 \beta$ treated or $H$ pylori infected AGS cells}

We have previously shown that MMP-3 secretion by AGS cells is increased during $H$ pylori infection. ${ }^{19}$ In the present study, we addressed the role of IL- $1 \beta$ in induction of MMP- 3 secretion. Concentrated serum free media were analysed by immunoblotting using an MMP-3 monoclonal antibody. Figure 3 shows a typical MMP-3 immunoblot together with densitometric 

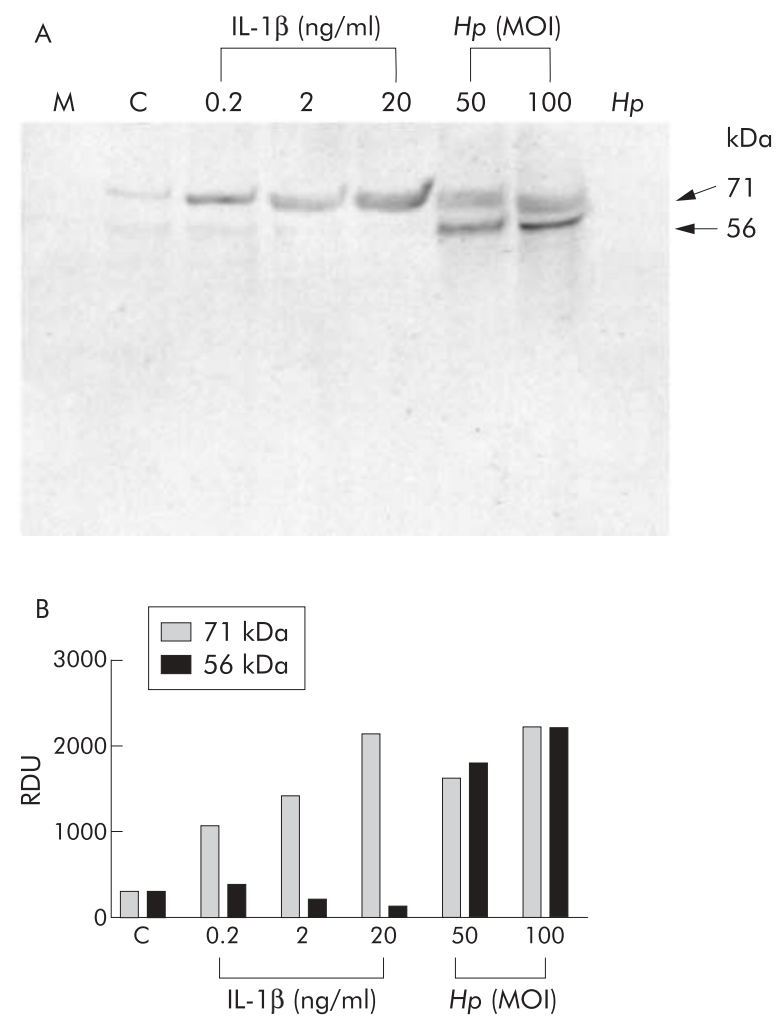

Figure 3 (A) Matrix metalloproteinase 3 (MMP-3) expression in serum free culture media conditioned by interleukin (IL)-1 $\beta$ treated or $H$ pylori infected AGS cells, as measured by non-reducing sodium dodecyl sulphate-polyacrylamide gel electrophoresis immunoblot analysis using MMP-3 specific monoclonal antibody. Lane M, cell culture medium alone; lane $C$, medium from untreated/uninfected AGS cells. (B) Densitometric analysis of immunoreactive bands. The blot is a representative replicate selected from three experiments. $\mathrm{Hp}$, Helicobacter pylori; MOI, multiplicity of infection; RDU, relative densitometric units.

analysis of immunoreactive bands. MMP-3 immunoreactivities of unconditioned medium and in medium conditioned by untreated AGS cells are shown in lanes $\mathrm{M}$ and $\mathrm{C}$, respectively.

In media conditioned by IL-1 $\beta$ or $H$ pylori treated AGS cells, immunoreactivity was detected at $56 \mathrm{kDa}$ and $71 \mathrm{kDa}$. Densitometric analysis of the immunoreactive bands showed that $H$ pylori treatment ( $\mathrm{MOI}=50$ and 100 ) of AGS cells induced dose dependent increases in both $56 \mathrm{kDa}$ and $71 \mathrm{kDa}$ bands whereas IL-1 $\beta \quad(0.2-2 \mathrm{ng} / \mathrm{ml})$ treatment induced a dose dependent increase only of the $71 \mathrm{kDa}$ band. Concentrated serum free media conditioned by $H$ pylori alone did not show any MMP-3 immunoreactivity. Because the molecular mass of TIMP-3 is $24 \mathrm{kDa}$ and because TIMP-3 is known to form SDS stable heterodimers with MMP- $3,{ }^{3}$ we hypothesised that the $71 \mathrm{kDa}$ band represented an MMP-3/TIMP-3 heterodimer, and that IL- $1 \beta$ treatment, like $H$ pylori infection, increased both MMP-3 and TIMP-3 secretion by AGS cells. In the case of IL- $1 \beta$ treatment alone, however, MMP-3 is immediately complexed with TIMP-3 and so is present mainly as a $71 \mathrm{kDa}$ band on the gel. Thus the traces of $56 \mathrm{kDa}$ immunoreactivity in IL- $1 \beta$ treated lanes $(0.2-2 \mathrm{ng} / \mathrm{ml})$ reflect the presence of uncomplexed MMP-3.

\section{TIMP-3 secretion by IL- $1 \beta$ treated or $H$ pylori infected AGS cells}

As a test of this hypothesis, the TIMP-3 content of culture media conditioned by IL- $1 \beta$ treated or $H$ pylori infected AGS cells was assessed by immunoblotting with a polyclonal TIMP-3 antibody. As shown in fig 4, TIMP-3 antibody labelled a $71 \mathrm{kDa}$ band in medium conditioned by IL-1 $\beta$ treated or $H$
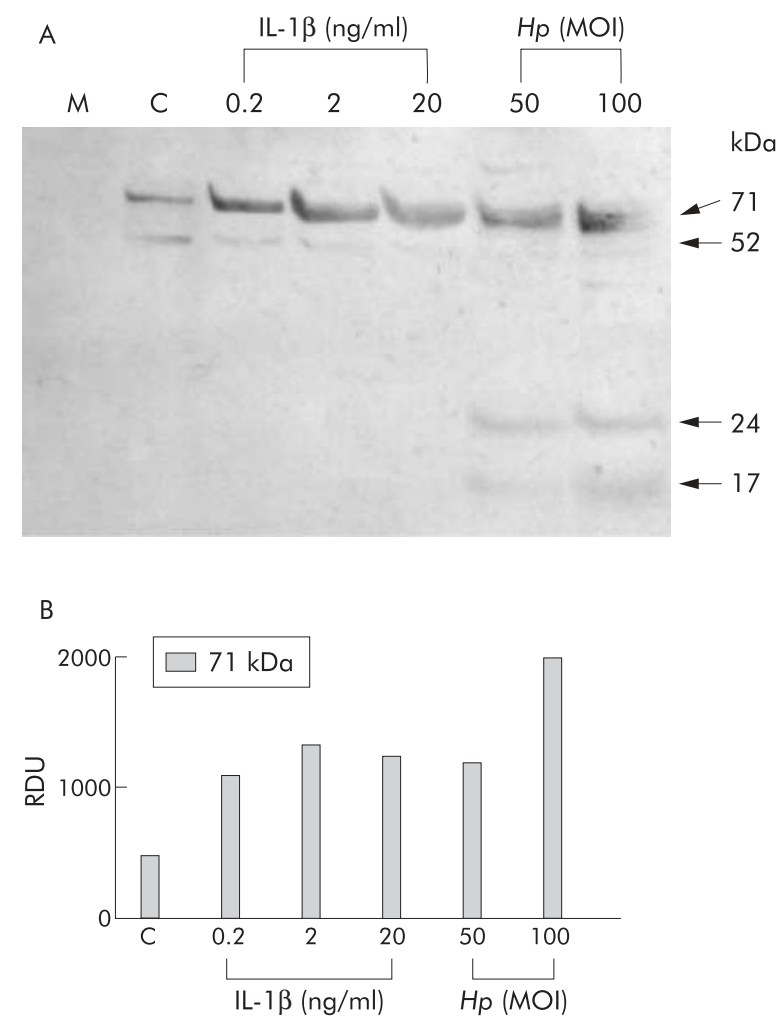

Figure 4 (A) Tissue inhibitor of metalloproteinase 3 (TIMP-3) expression in serum free culture media conditioned by interleukin (IL) - $1 \beta$ treated or $H$ pylori (Hp) infected AGS cells, as measured by non-reducing sodium dodecyl sulphate-polyacrylamide gel electrophoresis immunoblot analysis using polyclonal TIMP-3 antibody. Lane $M$, cell culture medium alone; lane $C$, medium from untreated/uninfected AGS cells. (B) Densitometric analysis of immunoreactive bands. The blot is a representative replicate selected from three experiments. MOI, multiplicity of infection; RDU, relative densitometric units.

pylori infected AGS cells. Densitometric analysis revealed dose dependent increases in TIMP-3 immunoreactivity of the 71 kDa band induced by IL- $1 \beta(0.2-20 \mathrm{ng} / \mathrm{ml})$ treatment and $H$ pylori infection (MOI of 50 and 100). We have previously shown that this TIMP-3 antibody also recognises a bacterial TIMP-3-like factor. ${ }^{19}$ Thus the $71 \mathrm{kDa}$ band detected in media conditioned by $H$ pylori infected AGS cells reflects both human and bacterial TIMP-3 complexes. The $24 \mathrm{kDa}$ and $17 \mathrm{kDa}$ bands represent uncomplexed bacterial and/or human TIMP-3 immunoreactivity, and the $52 \mathrm{kDa}$ band is most probably a TIMP-3 dimer. The data indicate that IL- $1 \beta$ at $2 \mathrm{ng} / \mathrm{ml}$ and $H$ pylori at MOI of 50, and IL- $1 \beta$ at $20 \mathrm{ng} / \mathrm{ml}$ and $H$ pylori at MOI of 100, induce comparable secretion of TIMP-3. This contrasts with the significantly higher secretion of MMP-3 induced by $H$ pylori compared with IL-1 $\beta$ (fig 2).

\section{Co-immunoprecipitation of MMP-3 and TIMP-3}

Further confirmation that the 71 kDa TIMP-3 immunoreactive bands are MMP-3/TIMP-3 complexes was obtained from co-immunoprecipitation experiments. MMP-3 complexes were immunoprecipitated from media conditioned by IL- $1 \beta$ treated $(2 \mathrm{ng} / \mathrm{ml})$ or $H$ pylori infected $(\mathrm{MOI}=50)$ AGS cells showing comparable TIMP-3 immunoreactivity. The immunoprecipitates were analysed by non-denaturing TIMP-3 immunoblotting. As shown in fig 5, more TIMP-3 immunoreactivity was detected in $H$ pylori infected $(\mathrm{MOI}=50)$ than in $\mathrm{IL}-1 \beta$ treated $(2 \mathrm{ng} / \mathrm{ml})$ AGS cell conditioned media. This result confirms the data in fig 3 and supports the hypothesis that $H$ pylori induces formation of more MMP-3/TIMP-3 complexes than IL-1 $\beta$. Because comparable TIMP-3 complexes were formed in 


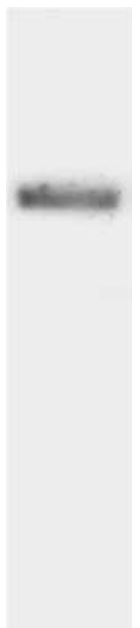

\section{AGSIL-1 $\beta$}

$(2 \mathrm{ng} / \mathrm{ml})$

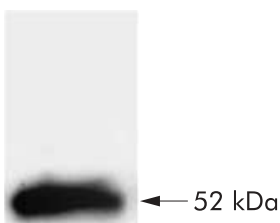

AGSHp

$(\mathrm{MOI}=50)$
Figure 5 Co-precipitation of tissue inhibitor of metalloproteinase 3 (TIMP-3) with matrix metalloproteinase 3 (MMP-3) immunoprecipitates from interleukin (IL)- $1 \beta$ treated $(2 \mathrm{ng} / \mathrm{ml})$ or $H$ pylori infected ( $\mathrm{Hp}$ multiplicity of infection $(\mathrm{MOI})=50$ ) AGS cell conditioned serum free media, as measured by non-reducing sodium dodecyl sulphate-polyacrylamide gel electrophoresis immunoblot analysis of MMP-3 monoclonal antibody immunoprecipitates using TIMP-3 poyclonal antibody. The blot is a representative replicate selected from two experiments.

both treatment conditions (fig 4), it is possible that during IL- $1 \beta$ treatment enzymes other than MMP-3 (MMPs or other matrix proteases) may form complexes with TIMP-3.

\section{MMP-3 enzyme activity in AGS cell conditioned media}

The enzymatic activity of MMP-3 secreted into media conditioned by IL- $1 \beta$ treated or $H$ pylori infected AGS cells was measured using the synthetic fluorogenic MMP-3 specific substrate M2110. Media were concentrated 100-fold by ammonium sulphate precipitation and incubated with M2110. The rate of M2110 hydrolysis was measured as changes in emitted fluorescence as a function of time (fluorescence units/s) and was expressed as a percentage of the initial reaction velocity of MMP-3 specific protease in untreated AGS cell conditioned media (table 1). Both IL-1 $\beta$ and $H$ pylori elicited dose dependent increases in evoked fluorescence: however, 24 times more MMP-3 activity was expressed in $H$ pylori treated compared with IL- $1 \beta$ treated AGS cell conditioned media. The combination of IL-1 $\beta$ treatment with $H$ pylori infection decreased the MMP-3 activity compared with $H$ pylori infection alone. Statistical analysis revealed a significant $(\mathrm{p}<0.001)$ interaction between IL-1 $\beta$ treatment and $H$ pylori infection.

We showed previously that $H$ pylori alone secreted MMP-3like activity and that host-cell interaction was needed for significantly increased MMP-3 activity in the cell medium. ${ }^{3}$ The latter result is consistent with data in the present study-that is, $H$ pylori induced MMP-3 activity is significantly higher than IL- $1 \beta$ induced MMP- 3 activity. Furthermore, these data were consistent with immunoblot data showing higher MMP-3 immunoreactivity in $H$ pylori infected compared with IL-1 $\beta$ treated AGS cell conditioned media.

\section{DISCUSSION}

In this study, we tested the hypothesis that activation of gastric epithelial matrix metalloproteinases by $H$ pylori infection is mediated by the proinflammatory cytokine IL- $1 \beta$. In an earlier study, we showed that gastric epithelial cells secrete MMP-1 and MMP-3 and that $H$ pylori infection increases
Table 1 Effects of interleukin (IL)- $1 \beta$ and Helicobacter pylori on matrix metalloproteinase 3 (MMP-3) activity of AGS cell conditioned media

\begin{tabular}{|c|c|}
\hline Sample & $\begin{array}{l}\text { Initial reaction velocity } \\
\text { (\% of AGS) }\end{array}$ \\
\hline AGS & $100(5)$ \\
\hline AGS+IL-1 $\beta(0.2 \mathrm{ng} / \mathrm{ml})$ & $144(26)^{* *}$ \\
\hline AGS+lL-1ß (2 ng/ml) & $149(20)^{* *}$ \\
\hline AGS+IL-1 $\beta(20 \mathrm{ng} / \mathrm{ml})$ & $199(11)^{* *}$ \\
\hline$A G S+H p$ & $2375(11)^{* *}$ \\
\hline$A G S+H p+I L-1 \beta(0.2 \mathrm{ng} / \mathrm{ml})$ & $2042(12)^{* *}$ \\
\hline$A G S+H p+I L-1 \beta(2 \mathrm{ng} / \mathrm{ml})$ & $1662(6)^{* *}$ \\
\hline$A G S+H p+I L-\beta(20 \mathrm{ng} / \mathrm{ml})$ & $1944(7)^{* *}$ \\
\hline Helicobacter pylori & $291(39)^{\text {* * }}$ \\
\hline Medium & $11(8)^{* *}$ \\
\hline
\end{tabular}

Hydrolysis of M21 10, an MMP-3 specific synthetic fluorogenic susbstrate, by concentrated serum free culture media of IL-1 $\beta$ treated $(0.2-20 \mathrm{ng} / \mathrm{ml})$ and $/$ or $H$ pylori infected $(M O I=50)$ AGS cells and bacterial supernatant alone $(H p)$.

Data are expressed as a percentage of the initial reaction velocity of MMP-3 activity in untreated AGS cell conditioned medium (mean (SEM)).

Medium refers to cell culture medium alone and AGS refers to untreated/uninfected AGS cell conditioned medium $(n=3)$ MMP-3 activity of every sample was significantly different from AGS $\left({ }^{* *} \mathrm{p}<0.01\right)$. Interaction between IL- $1 \beta$ and $\mathrm{H}$ pylori, as calculated by two way ANOVA, was $p<0.001$.

secretion of both metalloproteinases. ${ }^{19} \mathrm{H}$ pylori infection is known to induce IL-8 secretion by gastric epithelial cells, a response which is also elicited by cell stimulation with IL-1 $\beta{ }^{23}$ In the present study, gastric epithelial cell MMP secretion was measured in response to an IL- $1 \beta$ stimulus inducing the same amplitude of IL-8 secretory response as the $H$ pylori MOIs required to activate gastric epithelial MMP secretion. This IL- $1 \beta$ stimulus was within the range of IL- $1 \beta$ concentrations reported in studies of transcriptional factor nuclear factor $\mathrm{KB}$ activation of gastric cancer cells during $H$ pylori infection ${ }^{24}$ or MMP activation by cytokines. ${ }^{25-27}$

Induction of MMP-3 secretion was investigated because although gastric epithelial cell MMP-1 secretion was increased during $H$ pylori infection, ${ }^{19}$ the significantly higher rates of MMP-3 over MMP-1 secretion suggested that stromelysin-1 (MMP-3) and not MMP-1 is the major contributor to gastric epithelial degradation. Stromelysin-1 displays a wide spectrum of proteolytic activity against extracellular matrix proteins, and so increased MMP-3 activity would be expected to accelerate stromal degradation..$^{28}$ The present study comparing caseinolytic activity of $\mathrm{H}$ pylori or IL- $1 \beta$ treated gastric cell conditioned media showed that comparable MMP-1/MMP-3 activity ratios are induced by both treatments. The MMP-3 specific immunoblot data, immunoprecipitation data, and enzyme activity data all indicate that IL-1 $\beta$ dose dependently increased gastric epithelial cell MMP-3 secretion, providing a mechanistic basis for augmented epithelial degradation.

Several previous studies have documented regulation of TIMP-3 expression by IL- $1 \beta$. Gene expression of TIMP-3 was induced by IL-1 $\beta$ in human synovial lining cells ${ }^{29}$ and in rat granulosa cells. ${ }^{25}$ In contrast, IL-1 $\beta$ downregulated TIMP-3 expression in neonatal rat ventricular cells, ${ }^{26}$ in brain microvascular endothelial cells, ${ }^{27}$ and in human endometrial stromal cells. ${ }^{30}$ The present study provides evidence that IL-1 $\beta$ regulates TIMP-3 expression in human gastric epithelial cells. In addition to increasing MMP-3 secretion, IL- $1 \beta$ also elicited a dose dependent increase in TIMP-3 secretion by gastric epithelial cells. Most of the secreted MMP-3 was complexed by TIMP-3, leading to inhibition of stromelysin-1 activity. ${ }^{28}$ In the present study, $H$ pylori infected AGS cell conditioned media expressed higher levels of TIMP-3 than IL- $1 \beta$ treated AGS cell conditioned media. The polyclonal TIMP-3 antibody used in 


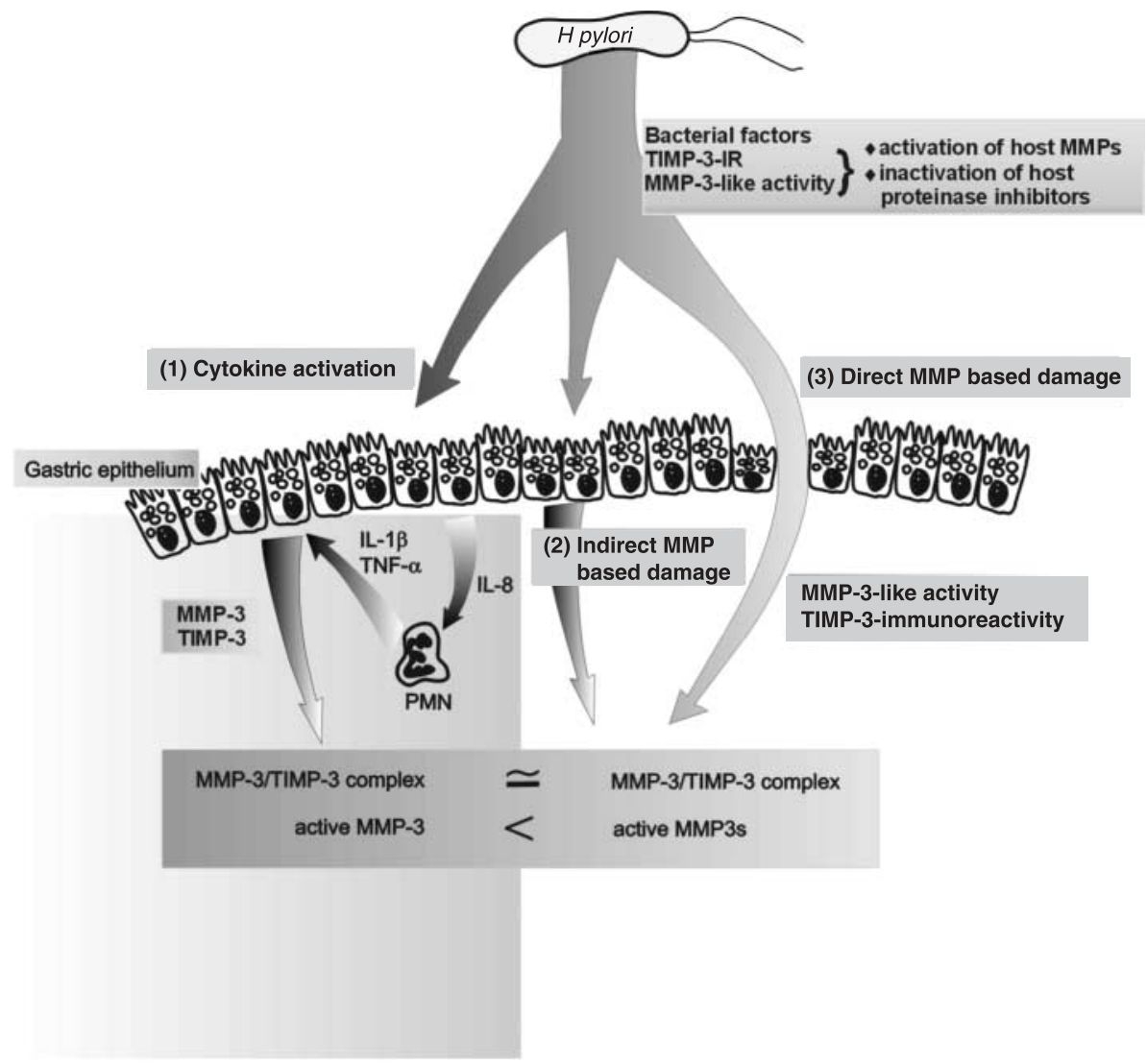

Figure 6 A model of gastric mucosal interactions between matrix metalloproteinases (MMPs) and their inhibitors (TIMPs) with the cytokine cascade during Helicobacter pylori infection. $H$ pylori induces epithelial MMP-3 secretion by: (1) interleukin (IL)-8, tumour necrosis factor $\alpha$ $(\mathrm{TNF}-\alpha)$, and IL-1 $\beta$ dependent mechanisms; (2) cytokine independent mechanisms; and (3) is directly enhanced by $H$ pylori metalloproteinases. Epithelial MMP-3 activity stimulated by IL- $1 \beta$ alone is effectively titrated by MMP-3/TIMP-3 complex formation. However, the increased MMP-3 tissue level induced by $H$ pylori infection is incompletely titrated by increased TIMP-3 secretion, indicating that IL- $1 \beta$ alone is necessary but insufficient to mediate the full gastric epithelial cell MMP activation response induced by $\mathrm{H}$ pylori infection.

this study was previously shown to cross react with $H$ pylori proteins. ${ }^{19}$ However, as shown by our immunoblot and enzyme activity data, the increased amount of TIMP-3 did not complex all available human immunoreactive MMP-3, and did not inhibit the increased human and bacterial MMP-3 enzymatic activity. Because MMPs and TIMPs are critical for tissue remodelling, and disturbances in MMP/TIMP balance play important roles in pathophysiological processes such as stromal degradation, our data showing IL-1 $\beta$ and $H$ pylori modulation of MMP-3 and TIMP-3 expression in gastric epithelial cells indicate potential $H$ pylori mediated mechanisms of gastric epithelial damage. Figure 6 is a schematic diagram incorporating the present MMP and TIMP data into the gastric mucosal cytokine cascade during $H$ pylori infection.

At least two mechanisms may account for the observed higher efficiency of $H$ pylori in stimulating MMP-3 activity compared with IL-1 $\beta$. Firstly, the high MMP-3 activity detected in $H$ pylori treated AGS cell conditioned media reflects both human MMP-3 and H pylori MMP-3-like activity. As the MMP-3 monoclonal antibody used in this study does not cross react with any $H$ pylori proteins, ${ }^{19}$ the immunoreactive bands represent only MMP-3 secreted by AGS cells; however, $H$ pylori MMP-3-like activity is also measured in the specific fluorogenic substrate based activity assay. The H pylori MMP-3-like proteinase potentially contributes to activation of host MMPs and activation of chemotactic pathways, while the $H$ pylori TIMP-3-like activity $^{19}$ inactivates host protease inhibitors. Alternatively, or concomitantly, MMP-3 activation may be promoted by $H$ pylori induced activation of cytokines other than IL- $1 \beta$, including GRO/CINC- $1,{ }^{31}$ and TNF- $\alpha .{ }^{32}$ As a putative $H$ pylori pathogenicity factor, MMP-3 complements two previously described $H$ pylori metalloproteases, one of which is similar to Vibrio cholerae mucinase ${ }^{33}$ and the other a $\mathrm{Zn}$ dependent $200 \mathrm{kDa}$ metalloproteinase. ${ }^{34}$

The cytokine-chemokine network and matrix metalloproteinases are increasingly understood to converge and cooperate in tumour cell metastasis and cancer cell resistance. Although MMPs are recognised as important regulatory proteases of chemokines, ${ }^{16} 35$ the relative contributions of inflammatory cytokines to activation of host MMPs are complex and as yet poorly defined. ${ }^{24}{ }^{32}{ }^{36}$ In addition to inducing IL-8 secretion, IL- $1 \beta$ and $H$ pylori also affect proliferation of gastric epithelial cells in culture, ${ }^{37}$ although data concerning the direct effects of IL- $1 \beta$ in $H$ pylori infection in vivo are conflicting. ${ }^{38}{ }^{39}$

In summary, the present study provides further evidence of interaction between cytokines and MMPs in promoting host responses to $H$ pylori infection. The proinflammatory cytokine IL- $1 \beta$, secretion of which is activated during gastric $H$ pylori infection as part of the cytokine cascade, contributes to enhanced MMP-3 and TIMP-3 secretion by H pylori infected gastric epithelial cells. Although most of the secreted MMP-3 is complexed by endogenous tissue inhibitor of MMP-3, the remaining balance of active MMP-3 may contribute to the mucosal damage during $H$ pylori infection. In addition to IL-1 $\beta$, other bacterial factors including bacterial MMP-3 are needed to mediate the full gastric epithelial cell MMP activation response induced by $H$ pylori infection.

\section{Authors' affiliations}

M Gööz , M Shaker, A J Smolka, Gastroenterology and Hepatology Division, Department of Medicine, Medical University of South Carolina, 
Charleston, SC, USA

P Gööz, Rheumatology and Immunology Division, Department of Medicine, Medical University of South Carolina, Charleston, SC, USA

\section{REFERENCES}

1 Labigne A, de Reuse H. Determinants of Helicobacter pylori pathogenicity. Infect Agents Dis 1996;5:191-20.

2 Crabtree JE. Immune and inflammatory responses to Helicobacter pylori infection. Scand J Gastroenterol 1996;31(suppl 215):3-10

3 Yamaoka Y, Kita M, Kodama T, et al. Induction of various cytokines and development of severe mucosal inflammation by cag gene positive Helicobacter pylori strains. Gut 1997:41:442-51.

4 Noah LA, Bosma NB, Jansen J, et al. Mucosal tumor necrosis factor- $\alpha$, interleukin- $1 \beta$, and interleukin-8 production in patients with Helicobacter pylori infection. Scand J Gastroenterol 1994;29:425-9

5 Sharma SA, Tummuru MK, Miller GG, et al. Interleukin- 8 response of gastric epithelial cell lines to Helicobacter pylori stimulation in vitro. Infect Immun 1994:63:1681-7.

6 Mobley HLT, Cortesia M, Rosenthal LE, et al. Characterization of urease from Campylobacter pylori. J Clin Microbiol 1988;26:831-6.

7 Cave DR. Vargas M. Effect of a Campylobacter pylori protein on acid secretion by parietal cells. Lancet 1989;2:187-9.

8 Beil W, Birkholz C, Wagner S, et al. Interaction of Helicobacter pylori and its fatty acids with parietal cells and gastric H,K-ATPase. Gut 1994; 35: 1 176-80.

9 Uehara A, Okumura T, Sekiya C, et al. Interleukin- 1 inhibits the secretion of gastric acid in rats: possible involvement of prostaglandin. Biochem Biophys Res Commun 1989;162:1578-84.

10 Gööz M, Hammond C, Larsen K, et al. Inhibition of human gastric $\mathrm{H}, \mathrm{K}-\mathrm{ATPase}$ subunit gene expression by $\mathrm{H}$. pylori. Am J Physiol 2000;278: G981-91.

11 Ernst PB, Crowe SE, Reyes VE. How does Helicobacter pylori cause mucosal damage? The inflammatory response. Gastroenterology 1997: 113:S35-42.

12 Odenbreit S, Puls J, Sedlmaier B, et al. Translocation of Helicobacter pylori CagA into gastric epithelial cells by type IV secretion. Science 2000;287: 1497-500.

13 Atherton JC, Cao P. Peek RM Jr, et al. Mosaicism in vacuolating cytotoxin alleles of Helicobacter pylori. Association of specific vacA types with cytotoxin production and peptic ulceration. J Biol Chem 1995;270: 17771-7.

14 Peek RM Jr, Thompson SA, Donahue JP, et al. Adherence to gastric epithelial cells induces expression of a Helicobacter pylori gene, iceA, that is associated with clinical outcome. Proc Assoc Am Physicians 1998:110:531-44

15 Israel DA, Salama N, Arnold CN, et al. Helicobacter pylori strains-specific differences in genetic content, identified by microarray, influence host inflammatory responses. J Clin Invest 2001; 107:61 1-20.

16 McQuibban GA, Gong JH, Tam EM, et al. Inflammation dampened by gelatinase A cleavage of monocyte chemoattractant protein-3. Science 2000;289: 1202-6.

17 Tatsuguchi A, Fukuda Y, Ishizaki M, et al. Localiation of matrix metalloproteinases and tissue inhibitors of metalloproteinases- 2 in normal human and rabbit stomach. Digestion 1999;60:246-54.

18 Saarialho-Kere UK, Vaalamo M, Puolakkainen P, et al. Enhanced expression of matrilysin, collagenase, and stromelysin- 1 in gastrointestinal ulcers. Am J Pathol 1996:148:519-26.

19 Göõz M, GöÄz P, Smolka AJ. Epithelial and bacterial metalloproteinases and their inhibitors in $\mathrm{H}$. pylori infection of gastric epithelial cells. Am J Physiol 2001;281:G823-32.
20 Pender LFS, McKenzie C, Shaida A, et al. Regulation of matrix metalloproteinases in human intestinal mucosa. Gastroenterol Suppl 1999:116:A793.

21 Tewari DS, Qian Y, Tewari M, et al. Mechanistic features associated with induction of metalloproteinases in human gingival fibroblasts by interleukin-1. Arch Oral Biol 1994;39:657-64.

22 El-Omar EM, Carrington M, Chow WH, et al. Interleukin-1 polymorphisms associated with increased risk of gastric cancer. Nature 2000;404:398-402

23 Yamada H, Aihara T, Okabe S. Mechanism for Helicobacter pylori stimulation of interleukin-8 production in a gastric epithelial cell line (MKN 28): roles of mitogen-activated protein kinase and (MKN 28): roles of mitogen-activated protein kinase and

24 Beales I, Calam J. Interleukin- $1 \beta$ and tumour necrosis factor- $\alpha$ inhibit acid secretion in cultured rabbit parietal cells by multiple pathways. Gut 1998;42:227-34

25 Nothnick WB, Curry TE. Divergent effects of interleukin- 1 beta on steroidogenesis and matrix metalloproteinase inhibitor expression and activity in cultured rat granulosa cells. Endocrinol 1996:137:3784-90.

26 Li YY, McTiernan CF, Feldman AM. Proinflammatory cytokines regulate tissue inhibitors of metalloproteinases and disintegrin metalloproteinase in cardiac cells. Cardiovasc Res 1999;42:162-72.

27 Bugno M, Witek B, Bereta J, et al. Reprogramming of TIMP-1 and TIMP-3 expression profiles in brain microvascular endothelial cells and astrocytes in response to proinflammatory cytokines. FEBS Lett 1999;448:9-14.

28 Parks WC and Mecham RP, editors. Matrix Metalloproteinases. San Diego: Academic, 1998:1-14.

29 Gatsios P, Haubeck HD, Van de Leur E, et al. Oncostatin M differentially regulates tissue inhibitors of metalloproteinases TIMP-1 and TIMP-3 gene expression in human synovial lining cells. Eur J Biochem 1996;241:56-63

30 Huang HY, Wen Y, Irwin JC, et al. Cytokine-mediated regulation of 92 kDa type IV collagenase, tissue inhibitor or metalloproteinase-1 (TIMP-1), and TIMP-3 messenger ribonucleic acid expression in human endometrial stromal cells. J Clin Endocrinol Metab 1998:83:1721-9.

31 Suzuki H, Mori M, Seto K, et al. Rat CXC chemokine GRO/CINC-1 paradoxically stimulates the growth of gastric epithelial cells. Aliment Pharmacol Ther 2000;14:94-100

32 Beales ILP, Post L, Calam J, et al. Tumor necrosis factor alpha stimulates gastrin release from canine and human antral G-cells: possible mechanism of the Helicobacter pylori-gastrin link. Eur J Clin Invest 1996. 26:609-11

33 Smith AW, Chahal B, French GL. The human gastric pathogen Helicobacter pylori has a gene encoding an enzyme first classified as a mucinase in Vibrio cholerae. Molec Microbiol 1994;13:153-60.

34 Windle HJ, Kelleher D. Identification and characterization of a metalloprotease activity from Helicobacter pylori. Infect Immun 1997;65:3132-7

35 Overall CM, McQuibban GA, Clark-Lewis I, et al. CC and CXC tumor chemokines: New members of the MMP degradome. Proc Am Assoc Cancer Res 2002:43:439.

36 Beales IL, Calam J. Inhibition of carbachol stimulated acid secretion by interleukin 1 beta in rabbit parietal cells requires protein kinase C. Gut 2001;48:782-9

37 Beales ILP. Effect of interlukin-1 $\beta$ on proliferation of gastric epithelial cells in culture. BMC Gastroenterol 2002;2:7-14.

38 Fan XG, Kelleher D, Fan X, et al. Helicobacter pylori increases proliferation of gastric epithelial cells. Gut 1996;38:19-22.

39 Tominaga K, Arakawa T, Tsuno M, et al. Increased mitogen-activated protein kinase activities stimulated with interleukin-1-beta and mechanism(s) of the kinase signaling pathways in rat gastric epithelial cells. Digestion 2000;61:30-8. 